\title{
Persamaan di Depan Hukum dalam Konteks Pengupahan dan Perekrutan Pekerja
}

\author{
Equality in Front of Law in Wages and Recruitment of \\ Workers
}

Rony Andre Christian Naldo' ${ }^{1}$, Christian Orchard Perangin-angin ${ }^{1)}$, Mesdiana

Purba $^{2)}$

1) Program Doktoral Hukum, Fakultas Hukum, Universitas Sumatera Utara, Indonesia

2) Jurusan Ilmu Hukum, Fakultas Hukum, Universitas Simalungun, Indonesia

Diterima: Januari 2019; Disetujui: Juni 2019; Dipublish: Juni 2019

*Coresponding Email: ronyandre87@ gmail.com, orchard27christian@ gmail.com

\section{Abstrak}

Aktivitas usaha PT. PN III tidak terlepas dari unsur pekerja. Dalam hubungan kerja, tentunya harus diterapkan persamaan didepan hukum. Fakta yang terjadi, ada diskriminasi dalam konteks pengupahan pekerja pria dan pekerja wanita. Selain itu, dalam konteks perekrutan pekerja, terjadi juga diskriminasi, yang lebih mengutamakan perekrutan pekerja pria dari pada pekerja wanita. Penelitian ini membahas mengenai persamaan didepan hukum dalam konteks pengupahan dan perekrutan pekerja pada PT. PN III. Sehubungan dengan itu, penelitian ini membahas secara khusus mengenai penyebab tidak diterapkannya persamaan didepan hukum dalam konteks pengupahan bagi pekerja wanita pada PT. PN III, dan penyebab lebih diutamakannya perekrutan pekerja pria dari pada pekerja wanita pada PT. PN III. Penelitian ini menggunakan jenis penelitian hukum normatif, dengan menggunakan metode yuridis normatif, dan bersifat deskriptif analitis. Sebagai kesimpulan, penyebab tidak diterapkannya persamaan didepan hukum dalam konteks pengupahan bagi pekerja wanita pada PT. PN III adalah akibat adanya ketentuan Pasal 44 ayat (1) dan (4) Perjanjian Kerja Bersama Periode 2016-2017 Antara PT. PN III Dengan SPBUN PT. PN III. Penyebab lebih diutamakannya perekrutan pekerja pria dari pada pekerja wanita pada PT. PN III adalah karena pekerja pria bekerja lebih efektif dari pada pekerja wanita.

Kata Kunci: Persamaan; Hukum; Pekerja

\section{Abstract}

PT. PN III is inseparable from workers. In work relations, of course equality must be applied before the law. In fact, there is discrimination in the context of wages for male and female workers. In addition, in the context of recruitment of workers, discrimination also occurs, which prioritizes the recruitment of male workers rather than female workers. This study discusses the similarities before the law in the context of wages and recruitment of workers at PT. PN III. In connection with this, this study specifically discusses the causes of not applying equality before the law in the context of wages for female workers at PT. PN III, and the cause of prioritization is the recruitment of male workers rather than female workers at PT. PN III. This study uses a type of normative legal research, using normative juridical methods, and is descriptive analytical. As a conclusion, the cause for not applying equality before the law in the context of wages for female workers at PT. PN III is a result of the provisions of Article 44 paragraph (1) and (4) Collective Labor Agreement for the 2016-2017 Period Between PT. PN III With SPBUN PT. PN III. The reason for prioritizing the recruitment of male workers is that female workers at PT. PN III is because male workers work more effectively than female workers.

Keywords: Equation; Law; The worker

How to Cite: Perangin-angin, C.O. Naldo, R.A.C. Purba, M. (2019). Persamaan di Depan Hukum dalam Konteks Pengupahan dan Perekrutan Pekerja, Jurnal Ilmiah Penegakan Hukum, 6 (1): 40 - 49. 


\section{PENDAHULUAN}

Hukum merupakan suatu produk politik yang dibentuk Pemerintah untuk mengatur kehidupan masyarakat, dengan sifatnya yakni mengatur dan memaksa. Dengan adanya hukum, diharapkan dapat tercipta keadilan, kepastian hukum, kemanfaatan, dan kebahagiaan dalam kehidupan masyarakat (Naldo dan Natasya, 2017; Mertokusumo, 1991; Sitorus dan Sierrad, 2006; Soekanto, 1993).

Hukum terbentuk dan berkembang sebagai suatu produk yang mencakup seluruh bidang dalam kehidupan masyarakat (Syahrin, 2009; BendaBeckmann, 1983). Perkembangan hukum dipengaruhi kultur, sejarah, dan juga waktu. Untuk itu maka hukum tidak boleh statis, akan tetapi hukum haruslah dinamis (Nonet dan Selznick, 1978; Friedman, 1977). Hukum mengendalikan keadilan, dimana keadilan tersebut haruslah memenuhi nilai-nilai. Pertama, persamaan kedudukan dihadapan hukum. Kedua, Hak Asasi Manusia (HAM). Ketiga, kebenaran. Keempat, kepatuhan. Kelima, melindungi masyarakat (Yahya, 1997; Pasal 1 angka 1 Undang-undang Nomor 39 Tahun 1999 tentang Hak Asasi Manusia).

Pasal 1 ayat (3) Undang-Undang Dasar Negara Republik Indonesia Tahun 1945 (UUD 1945), menentukan bahwa: "Indonesia adalah negara hukum" (Martosoewigyo, 1992; Burkens, 1990; Soemitro, 1976). Dengan status sebagai negara hukum, sesuai dengan ketentuan Pasal 27 ayat (1) UUD 1945, setiap orang sama kedudukannya didepan hukum dan wajib menjunjung hukum itu dengan tidak ada kecualinya (Pasal 27 angka 1 UUD 1945; Pasal 4 UU Nomor 39 Tahun 1999). Sesuai dengan ketentuan ayat (2), setiap orang berhak atas pekerjaan dan penghidupan yang layak bagi kemanusiaan (Pasal 27 angka 2 UUD 1945).

Hingga saat sekarang ini banyak Badan Usaha Milik Negara/BUMN (perusahaan negara) yang melaksanakan aktivitas usaha (Pasal 1 angka 1 Undangundang Nomor 19 Tahun 2003 tentang Badan Usaha Milik Negara; Anoraga,1995:90; Darwin dan Natasya, 2017; Pasal 1 nomor 5 Undang-undang Nomor 17 Tahun 2003). Salah satunya adalah PT. Perkebunan Nusantara III (PT. PN III) (Pasal 1 nomor 1 Undang-undang Nomor 40 Tahun 2007 tentang Perseroan Terbatas). Dalam melaksanakan aktivitas usahanya, tentunya PT. PN III sebagai perusahaan negara tidak terlepas dari unsur tenaga kerja (pekerja).

Tenaga kerja merupakan setiap orang yang mampu melakukan pekerjaan guna menghasilkan barang dan/atau jasa baik untuk memenuhi kebutuhan sendiri maupun untuk masyarakat (Pasal 1 nomor 2 Undang-undang Nomor 13 Tahun 2003 tentang Ketenagakerjaan). Pekerja merupakan setiap orang yang bekerja dengan menerima upah atau imbalan dalam bentuk lain (Pasal 1 nomor 3 UU Nomor 13 Tahun 2003).

Sesuai dengan pengertian tenaga kerja dan pengertian pekerja yang telah ditentukan pada Pasal 1 ayat (2) dan ayat (3) UU Nomor 13 Tahun 2003, pekerja tentunya tidak hanya terbatas pada pekerja pria, akan tetapi juga pekerja wanita. Demikian juga halnya pekerja pada PT. PN III.

Setiap pekerja (pria maupun wanita) pada PT. PN III, pada prinsipnya sama didepan hukum, dan berhak memperoleh upah. Dengan adanya persamaan didepan hukum, berdasarkan ketentuan Pasal 27 ayat (1) UUD 1945, idealnya upah pekerja pria dan pekerja wanita haruslah sama.

Fakta yang ada dalam hubungan kerja pada PT. PN III, upah pekerja pria lebih besar dari pada pekerja wanita (Pasal 1 nomor 15 UU Nomor 13 Tahun 2003). Fakta ini tentunya merupakan bentuk diskriminasi, dan jelas bertentangan dengan ketentuan Pasal 27 ayat (1) UUD 1945, serta Pasal 4 UU Nomor 39 Tahun 1999 (Pasal 1 nomor 3 UU Nomor 39 Tahun 1999). 
Selain adanya fakta perbedaan upah, fakta lainnya, hingga saat sekarang ini, pekerja wanita pada PT. PN III, untuk setiap tahunnya telah semakin berkurang kuantitasnya, karena dalam perekrutan pekerja, lebih diutamakan perekrutan pekerja pria dari pada pekerja wanita. Fakta ini tentunya juga merupakan bentuk diskriminasi terhadap pekerja wanita, yang selain jelas bertentangan dengan ketentuan Pasal 27 ayat (1) UUD 1945, Pasal 4 UU Nomor 39 Tahun 1999, juga jelas bertentangan dengan Pasal 27 ayat (2) UUD 1945.

Fakta adanya bentuk diskriminasi pada PT. PN III berupa perbedaan upah dan perekrutan yang lebih mengutamakan pekerja pria dari pada pekerja wanita, selain jelas bertentangan dengan ketentuan Pasal 27 ayat (1) dan ayat (2) UUD 1945 serta Pasal 4 UU Nomor 39 Tahun 1999, dikaji lebih lanjut berdasarkan ketentuan dalam UUD 1945, juga jelas bertentangan dengan ketentuan Pasal 28 D ayat (1) dan ayat (2) (Pasal 28 D nomor 1 UUD 1945).

\section{METODE PENELITIAN}

Penelitian ini menggunakan jenis penelitian hukum normatif (Soemitro, 1988:10). Metode yang digunakan adalah metode yuridis normatif (Soekanto dan Mamuji, 2004). Penelitian ini bersifat deskriptif analitis. Data penelitian ini seperti lazimnya penelitian hukum normatif, yaitu mempergunakan data sekunder baik dalam bentuk bahan hukum primer, sekunder, maupun tertier sebagai data utama/pokok penelitian (Soekanto, 1986; Sunggono, 2002).

Pengumpulan data dilakukan melalui studi library research, yaitu pengumpulan data dokumen, literatur dan mempelajari ketentuan peraturan perundang-undangan yang terkait dengan permasalahan yang akan dijawab dalam penelitian ini.

Seluruh data yang sudah diperoleh dan dikumpulkan selanjutnya akan ditelaah dan dianalisis secara kualitatif.
Kemudian diuraikan kembali untuk disajikan secara sistematis, sehingga menghasilkan pembahasan yang dapat digunakan untuk menjawab permasalahan dalam penelitian ini.

\section{HASIL DAN PEMBAHASAN}

Indonesia merupakan negara hukum. Negara hukum yang dimaksud adalah recht staat, dengan 4 (empat) unsur. Pertama, pengakuan dan perlindungan HAM. Kedua, negara didasarkan atas Trias Politika. Ketiga, pemerintahan didasarkan atas undang-undang (wegmatigeheid van bestuur). Keempat, ada peradilan administrasi yang berwenang terhadap kasus perbuatan melanggar hukum yang dilakukan Pemerintah (Atmadja, 2010).

Menurut Jimly Asshiddiqie, prinsipprinsip negara hukum senantiasa berputar pada 2 (dua) isu pokok yaitu masalah pembatasan kekuasaan dan perlindungan HAM, sehingga ada 12 (dua belas) prinsip pokok yang menjadi pilar utama penyangga negara hukum. Pertama, supremasi hukum (supremacy of law). Kedua, persamaan dalam hukum (equality before the law). Ketiga, asas legalitas (due process of law). Keempat, pembatasan kekuasaan. Kelima, organ-organ pendukung yang independen. Keenam, peradilan bebas tidak memihak. Ketujuh, Peradilan Tata Usaha Negara. Kedelapan, Peradilan Tata Negara (constitutional court). Kesembilan, perlindungan HAM. Kesepuluh, bersifat demokratis (democratische recht staat). Kesebelas, berfungsi sebagai sarana mewujudkan tujuan negara (welvaar recht staat). Kedua belas, transparansi dan kontrol sosial (Asshiddiqie, 2012).

Dengan status sebagai negara hukum, sesuai dengan ketentuan Pasal 27 ayat (1) UUD 1945, Pasal 4 UU Nomor 39 Tahun 1999, dan salah satu prinsip pokok yang menjadi pilar utama penyangga negara hukum menurut Jimly Asshiddiqie (prinsip persamaan dalam hukum), pada dasarnya setiap orang sama kedudukannya didepan 
hukum dan wajib menjunjung hukum itu dengan tidak ada kecualinya.

Di dalam hukum, istilah "person (orang)" mencakup mahluk pribadi, yakni manusia (natuurlijk persoon) dan badan hukum (persona moralis, legal person, legal entity, rechtspersoon). Keduanya adalah subjek hukum, sehingga keduanya adalah penyandang hak dan kewajiban hukum (Khairandy, 2009; Rahardjo, 2006; Hartono, 2006).

Hingga saat sekarang ini banyak BUMN yang melaksanakan aktivitas usaha. Salah satunya adalah PT. PN III. Dengan bentuk badan hukum PT, maka PT. PN III tentunya juga merupakan subjek hukum, yang merupakan pendukung hak dan kewajiban (drager van het recht en plicht).

Dalam melaksanakan aktivitas usahanya, tentunya PT. PN III sebagai perusahaan negara tidak terlepas dari unsur pekerja, yang tidak hanya terbatas pada pekerja pria, akan tetapi juga pekerja wanita. Setiap pekerja pada PT. PN III, pada prinsipnya sama di depan hukum, dan berhak memperoleh upah.

Upah merupakan hak dari setiap pekerja pada PT. PN III, yang diterima dan dinyatakan dalam bentuk uang sebagai imbalan dari PT. PN III sebagai pemberi kerja, yang ditetapkan dan dibayarkan menurut perjanjian kerja bersama, termasuk tunjangan bagi pekerja dan keluarganya atas pekerjaan dan/atau jasa yang telah atau akan dilakukan (Pasal 1 nomor 21 UU Nomor 13 Tahun 2003).

Berdasarkan ketentuan Pasal 27 ayat (1) UUD 1945, Pasal 4 UU Nomor 39 Tahun 1999, dan prinsip persamaan di depan hukum yang merupakan salah satu prinsip pokok yang menjadi pilar utama penyangga negara hukum menurut Jimly Asshiddiqie, idealnya upah pekerja pria dan pekerja wanita pada PT. PN III haruslah sama (tidak boleh ada diskriminasi).

Fakta yang ada dalam hubungan kerja pada PT. PN III, ada diskriminasi dalam konteks pengupahan pekerja pria dan pekerja wanita, dimana upah pekerja pria lebih besar dari pada pekerja wanita. Hal ini ditegaskan berdasarkan ketentuan Pasal 44 ayat (1) Perjanjian Kerja Bersama Periode 2016-2017 Antara PT. PN III Dengan Serikat Pekerja Perkebunan (SPBUN) PT. PN III, yang telah tercatat pada Dinas Tenaga Kerja dan Transmigrasi Pemerintah Propinsi Sumatera Utara.

Ditegaskan bahwa adanya
diskriminasi tersebut karena berdasarkan Pasal 44 ayat (1) Perjanjian Kerja Bersama Periode 2016-2017 Antara PT. PN III Dengan SPBUN PT. PN III tersebut, ada 3 (tiga) kriteria bagi pekerja wanita untuk dapat diperlakukan sebagai kepala keluarga (sehingga dapat sama pengupahannya didepan hukum dengan pekerja pria).

Pertama, berstatus janda karena suaminya meninggal dunia dan mempunyai tanggungan anak. Kedua, suami tidak mampu mencari nafkah akibat keadaan jasmani dan/atau rohani, yang harus dibuktikan dengan Surat Keterangan Dokter. Ketiga, berstatus janda karena perceraian berdasarkan putusan Pengadilan/surat keterangan yang sah yang menyatakan bahwa anak-anaknya menjadi tanggungannya.

Apabila salah satu dari ketiga kriteria tersebut dipenuhi, maka berdasarkan ketentuan Pasal 44 ayat (2) Perjanjian Kerja Bersama Periode 2016-2017 Antara PT. PN III Dengan SPBUN PT. PN III, pekerja wanita dianggap sebagai kepala keluarga, dan berhak menerima gaji, tunjangan, santunan sosial, dan berbagai penerimaan lain yang sah seperti yang berlaku bagi pekerja lainnya dengan status kawin.

Berdasarkan Pasal 44 ayat (4) Perjanjian Kerja Bersama Periode 20162017 Antara PT. PN III Dengan SPBUN PT. PN III, pekerja wanita yang menikah kembali, gugur statusnya diperlakukan sebagai kepala keluarga. Ketentuan ayat (4) ini, jika dikaji lebih lanjut berdasarkan UU Nomor 39 Tahun 1999, tentunya jelas 
bertentangan dengan ketentuan Pasal 10 ayat (1) UU Nomor 39 Tahun 1999 (Pasal 10 nomor 1 UU Nomor 39 Tahun 1999).

Telah ditegaskan bahwa Indonesia merupakan negara hukum. Sebagai negara hukum, salah satu tanggung jawab Pemerintah adalah untuk memberikan perlindungan bagi setiap warga negaranya. Perlindungan yang dimaksud adalah perlindungan hukum (Rahardjo, 2003).

Perlindungan hukum adalah memberikan pengayoman terhadap HAM yang dirugikan orang lain, dan perlindungan itu diberikan kepada semua warga negara agar dapat menikmati semua hak-hak yang diberikan oleh hukum (Hadjon, 1987). Hukum dapat difungsikan untuk mewujudkan perlindungan yang sifatnya tidak sekedar adaptif dan fleksibel, melainkan juga prediktif dan antisipatif. Hukum dibutuhkan untuk mereka yang lemah dan belum kuat secara sosial, ekonomi dan politik untuk memperoleh keadilan sosial (Rahardjo, 2003; Rasjidi dan Putra, 1993).

Dengan adanya fakta diskriminasi pengupahan pekerja pria dan pekerja wanita akibat pada PT. PN III akibat adanya kriteria bagi pekerja wanita untuk dapat diperlakukan sebagai kepala keluarga yang telah ditentukan Pasal 44 ayat (1) dan ayat (4) Perjanjian Kerja Bersama Periode 2016-2017 Antara PT. PN III Dengan SPBUN PT. PN III, tentunya fakta tersebut jelas bertentangan dengan ketentuan Pasal 27 ayat (1), ayat (2), Pasal 28 D ayat (1), ayat (2) UUD 1945, dan Pasal 4 dan Pasal 10 ayat (1) UU Nomor 39 Tahun 1999.

Perjanjian Kerja Bersama Periode 2016-2017 Antara PT. PN III Dengan SPBUN PT. PN III merupakan perjanjian yang diberlakukan secara umum bagi para pekerja pada PT. PN III. Dikaji berdasarkan Pasal 1338 Kitab Undang-undang Hukum Perdata (KUH Perdata), agar Perjanjian Kerja Bersama Periode 2016-2017 Antara PT. PN III Dengan SPBUN PT. PN III dapat berlaku sebagai undang-undang bagi para pihak yang terikat, maka tentunya semua ketentuan dalam perjanjian tersebut haruslah sesuai (tidak bertentangan) dengan undang-undang yang berlaku (Pasal 1338 KUH Perdata).

Ketentuan Pasal 44 ayat (1) dan (4) dalam Perjanjian Kerja Bersama Periode 2016-2017 Antara PT. PN III Dengan SPBUN PT. PN III, jelas merupakan ketentuan yang bertentangan dengan berbagai ketentuan dalam undang-undang yang berlaku, yakni ketentuan Pasal 27 ayat (1), ayat (2), Pasal 28 D ayat (1), ayat (2) UUD 1945, Pasal 4 dan Pasal 10 ayat (1) UU Nomor 39 Tahun 1999.

Untuk itu, maka sebenarnya Perjanjian Kerja Bersama Periode 20162017 Antara PT. PN III Dengan SPBUN PT. PN III, secara hukum belum layak diberlakukan sebagai undang-undang bagi para pihak yang terikat didalamnya. Hal ini ditegaskan karena masih ada ketentuannya yang bertentangan dengan berbagai ketentuan pasal dalam undangundang yang berlaku.

Fakta adanya diskriminasi dalam konteks pengupahan pekerja pria dan pekerja wanita pada PT. PN III akibat adanya ketentuan Pasal 44 ayat (1) dan (4) dalam Perjanjian Kerja Bersama Periode 2016-2017 Antara PT. PN III Dengan SPBUN PT. PN III, memberikan gambaran bahwa Pemerintah belum mampu secara maksimal memberikan perlindungan hukum bagi pekerja wanita pada PT.PN III, dan masih gagal melaksanakan amanat Pasal 27 ayat (1), ayat (2), Pasal 28 D ayat (1), ayat (2) UUD 1945, Pasal 4 dan Pasal 10 ayat (1) UU Nomor 39 Tahun 1999.

Berdasarkan pemaparan yang telah ada, ditegaskan bahwa penyebab tidak diterapkannya persamaan di depan hukum dalam konteks pengupahan bagi pekerja wanita pada PT. PN III adalah akibat adanya ketentuan Pasal 44 ayat (1) dan (4) dalam Perjanjian Kerja Bersama Periode 2016-2017 Antara PT. PN III Dengan SPBUN PT. PN III, yang menentukan kriteria bagi pekerja wanita untuk dapat 
diperlakukan sebagai kepala keluarga, yang akan gugur statusnya apabila menikah kembali, yang jelas bertentangan dengan ketentuan Pasal 27 ayat (1), ayat (2), Pasal 28 D ayat (1), ayat (2) UUD 1945, Pasal 4 dan Pasal 10 ayat (1) UU Nomor 39 Tahun 1999.

Selain fakta adanya bentuk diskriminasi berupa tidak diterapkannya persamaan didepan hukum dalam konteks pengupahan bagi pekerja wanita, dalam perekrutan pekerja pada PT. PN III, faktanya lebih diutamakan perekrutan pekerja pria dari pada pekerja wanita. Fakta ini mengakibatkan untuk setiap tahunnya telah semakin berkurang kuantitas pekerja wanita pada PT. PN III, yang tentunya juga merupakan bentuk diskriminasi yang menimbulkan ketidakadilan bagi pekerja wanita.

Salah satu tujuan hukum adalah keadilan. Menurut M. Yahya Harahap, hukum mengendalikan keadilan, dimana keadilan tersebut haruslah memenuhi nilai-nilai. Pertama, persamaan kedudukan dihadapan hukum. Kedua, HAM. Ketiga, kebenaran. Keempat, kepatuhan. Kelima, melindungi masyarakat (Yahya, 2003).

Teori John Rawls tentang keadilan dalam kaitannya dengan prinsip kesamaan (equality), bahwa setiap orang harus mempunyai hak yang sama untuk mendapatkan kebebasan yang sebesarbesarnya berdasarkan sistem kebebasan yang memberikan kesempatan yang sama kepada semua orang (Rawls, 1971).

Menurut John Rawls, ketidaksamaan atau ketidaksetaraan dibidang sosial ekonomi harus diatur secara menyeluruh agar golongan yang paling lemah merupakan pihak paling diuntungkan, dan setiap orang diberikan kesempatan yang sama. Formulasi asas keadilan dalam kehidupan sosial ekonomi yang ditawarkan John Rawls adalah mengatur kebebasan dan keadilan yang berkaitan dengan efisiensi ekonomi dan kesejahteraan.
Sejalan dengan itu, Friedman menyampaikan bahwa negara memiiki 4 (empat) peran dalam penyelenggaraan kesejahteraan umum melalui ekonomi yang berpihak pada rakyat. Pertama, negara sebagai penjamin (provider) kesejahteraan rakyat dimana negara menjamin standar minimum kehidupan warga negaranya dalam bentuk jaminan sosial. Kedua, negara sebagai pengatur (regulator) dimana negara menggunakan kekuasaannya untuk membuat peraturan atau kebijaksanaan untuk kesejahteraan rakyat. Ketiga, negara sebagai entrepreneur dimana negara menjalankan usaha ekonomi pada sektor tertentu melalui BUMN atau BUMD yang berdampingan dengan swasta dalam kegiatan ekonomi di Indonesia. Keempat, negara sebagai pengawas (umpire) dimana negara merumuskan/menilai standarstandar yang adil dalam kegiatan ekonomi sehingga kegiatan ekonomi dapat berjalan dengan adil (Abrar, 1999).

Telah dipaparkan bahwa dalam perekrutan pekerja pada PT. PN III, faktanya lebih diutamakan perekrutan pekerja pria dari pada pekerja wanita. Fakta ini mengakibatkan untuk setiap tahunnya telah semakin berkurang kuantitas pekerja wanita pada PT. PN III, yang merupakan bentuk diskriminasi dan menimbulkan ketidakadilan bagi pekerja wanita, yang jelas bertentangan dengan ketentuan Pasal 27 ayat (1), ayat (2), Pasal 28 D ayat (1), ayat (2) UUD 1945, dan Pasal 4 UU Nomor 39 Tahun 1999.

Dengan bentuk badan hukum PT sehingga PT. PN III juga merupakan subjek hukum yang harus mendukung hak dan kewajiban, seharusnya dalam konteks perekrutan pekerja, PT. PN III tidak diskriminasi dengan lebih mengutamakan perekrutan pekerja pria dari pada pekerja wanita. Dengan tidak diskriminasi (diberikan kesempatan yang sama), maka terpenuhilah keadilan menurut John Rawls. 
Dengan tidak adanya diskriminasi dalam konteks perekrutan pekerja pada PT. PN III, terciptalah keadilan, dan terakomodirlah hak untuk diperlakukan sama didepan hukum, serta hak untuk memperoleh pekerjaan bagi pekerja wanita, yang telah diamanatkan Pasal 27 ayat (1), ayat (2), Pasal 28 D ayat (1), ayat (2) UUD 1945, dan Pasal 4 UU Nomor 39 Tahun 1999.

Fakta lebih diutamakannya perekrutan pekerja pria dari pada pekerja wanita pada PT. PN III, memiliki penyebab. Berdasarkan penelitian, ditegaskan bahwa penyebab lebih diutamakannya perekrutan pekerja pria dari pada pekerja wanita pada PT. PN III adalah karena pekerja pria bekerja lebih efektif dari pada pekerja wanita.

Dikaji berdasarkan gender, memang tidak dapat dipungkiri bahwa pekerja wanita lebih lemah secara fisik apabila dibandingkan dengan pekerja pria, sehingga tepatlah jika lebih diutamakan perekrutan pekerja pria dari pada pekerja wanita pada PT. PN III, meskipun sebenarnya hal ini merupakan bentuk diskriminasi yang menimbulkan ketidakadilan bagi wanita.

Dikaji berdasarkan hukum, perbedaan gender tidak dapat dijadikan alasan pembenar untuk lebih mengutamakan perekrutan pekerja pria dari pada pekerja wanita pada PT. PN III, karena hal tersebut selain merupakan bentuk diskriminasi yang menimbulkan ketidakadilan bagi pekerja wanita, dan juga jelas bertentangan dengan ketentuan Pasal 27 ayat (1), ayat (2), Pasal 28 D ayat (1), ayat (2) UUD 1945, dan Pasal 4 UU Nomor 39 Tahun 1999.

Sesuai dengan pendapat Gustav Radburch, tujuan hukum tidak hanya terbatas pada keadilan, akan tetapi juga kemanfaatan dan kepastian hukum. Kemanfaatan dan kepastian hukum harus dapat dijadikan pondasi untuk menciptakan keadilan.
Teori Manfaat oleh Jeremy Bentham, berasal dari aliran utilitarianism yang mengutamakan asas manfaat (Daniel dan Mohamed, 2008). Menurut Jeremy Bentham, sesuatu dianggap benar apabila menghasilkan kebaikan (manfaat) yang lebih banyak daripada perbuatan yang lainnya.

Teori Manfaat memiliki 3 (tiga) unsur dalam menentukan manfaat suatu tindakan. Pertama, unsur evaluatif, yakni hal-hal yang menyebabkan suatu keadaan menjadi baik sehingga orang dapat membandingkan antara 2 (dua) keadaan yang mana yang lebih baik. Kedua, unsur konsensualis, yakni dimana hak atau pertanggungjawaban suatu tindakan bergantung pada konsekuensi yang dihasilkannya. Ketiga, unsur penerima manfaat, yakni siapa yang harus dipertimbangkan saat memperkirakan konsekuensi dari tindakan yang akan terjadi (Davies dan Holdcroft, 1991).

Asas manfaat bisa digunakan untuk membenarkan adanya undang-undang sebagai alat kontrol negara guna kepentingan umum maupun guna mencapai kebahagiaan (Bertens, 2000). Untuk itu maka dapat diberlakukan paksaan buat setiap subjek hukum mencegah merugikan subjek hukum lain dalam mencari kebahagiaan individual ataupun kelompoknya, dengan cara negara membatasi hak dan kewajiban setiap subjek hukum dalam undang-undang.

Kemanfaatan merupakan konsep dasar dalam berpikir secara hukum (het juridische denken). Untuk dapat dikategorikan sebagai peraturan hukum yang baik, maka peraturan hukum haruslah dapat memberikan kemanfaatan bagi semua orang tanpa diskriminasi.

Pasal 27 ayat (1), ayat (2), Pasal 28 D ayat (1), ayat (2) UUD 1945, dan Pasal 4 UU Nomor 39 Tahun 1999, merupakan peraturan hukum yang baik dan dapat memberikan manfaat bagi pekerja wanita pada PT. PN III, karena telah mengamanatkan tanpa diskriminasi untuk 
diterapkan dan diakomodir persamaan didepan hukum, hak atas pengakuan, hak atas jaminan dan perlindungan hukum, hak atas kepastian hukum yang adil, hak atas pekerjaan dan penghidupan yang layak bagi kemanusiaan, serta hak mendapat imbalan dan perlakuan yang adil dan layak dalam hubungan kerja.

Diskriminasi yang terjadi terhadap pekerja wanita pada PT. PN III berupa tidak diterapkannya persamaan didepan hukum dalam konteks pengupahan, tidak lain hanyalah diakibatkan ketentuan Pasal 44 ayat (1) dan (4) Perjanjian Kerja Bersama Periode 2016-2017 Antara PT. PN III Dengan SPBUN PT. PN III, yang notabene pasal tersebut tidak sesuai dengan amanah Pasal 27 ayat (1), ayat (2), Pasal 28 D ayat (1), ayat (2) UUD 1945, dan Pasal 4 UU Nomor 39 Tahun 1999.

Diskriminasi terhadap pekerja wanita pada PT. PN III berupa lebih diutamakannya perekrutan pekerja pria dari pada pekerja wanita, mungkin tidak lebih hanya sekedar didasarkan pada kebijakan PT. PN III dengan dasar pertimbangan bahwa pekerja pria bekerja lebih efektif dari pada pekerja wanita. Akan tetapi, harus juga diingat, bahwa salah satu syarat untuk membuat kebijakan adalah bahwa kebijakan tersebut tidak bertentangan dengan undang-undang.

Lebih diutamakannya perekrutan pekerja pria dari pada pekerja wanita, selain merupakan bentuk diskriminasi, yang juga jelas bertentang dengan undangundang, yakni Pasal 27 ayat (1), ayat (2), Pasal 28 D ayat (1), ayat (2) UUD 1945, dan Pasal 4 UU Nomor 39 Tahun 1999.

Telah dipaparkan bahwa sebagai negara hukum, salah satu tanggung jawab Pemerintah adalah untuk memberikan perlindungan hukum bagi setiap warga negaranya. Perlindungan hukum adalah memberikan pengayoman terhadap HAM yang dirugikan orang lain, dan perlindungan itu diberikan kepada semua warga negara agar dapat menikmati semua hak-hak yang diberikan oleh hukum.

Agar pekerja wanita pada PT. PN III yang notabene merupakan warga negara dapat diayomi HAM-nya yang telah dirugikan akibat adanya diskriminasi dalam konteks pengupahan dan perekrutan, sehingga kelak pekerja wanita mendapatkan manfaat dari hak-haknya yang diberikan hukum, maka Pemerintah melalui kementerian terkait haruslah melaksanakan kewajiban dan tanggung jawabnya dalam rangka penegakan hukum dan HAM, sebagaimana yang telah ditentukan pada Pasal 71 dan Pasal 72 UU Nomor 39 Tahun 1999 (Pasal 71 UU Nomor 39 Tahun 1999).

Upaya yang dapat dilaksanakan Pemerintah adalah berupa memerintahkan PT. PN III untuk segera merevisi ketentuan Pasal 44 Perjanjian Kerja Bersama Periode 2016-2017 Antara PT. PN III Dengan SPBUN PT. PN III, dan memerintahkan PT. PN III agar tidak diskriminasi berdasarkan gender dalam hal perekrutan pekerja.

Melalui pelaksanaan kedua upaya di atas, maka diharapkan pada masa yang akan datang tidak lagi terjadi diskriminasi dalam konteks pengupahan dan perekrutan pekerja pada PT. PN III, yang secara otomatis mewujudkan persamaan didepan hukum, keadilan, perlindungan hukum, kepastian hukum, dan kemanfaatan, khususnya bagi pekerja wanita pada PT. PN III.

\section{SIMPULAN}

Penyebab tidak diterapkannya persamaan didepan hukum dalam konteks pengupahan bagi pekerja wanita pada PT. PN III adalah akibat adanya ketentuan Pasal 44 ayat (1) dan (4) Perjanjian Kerja Bersama Periode 2016-2017 Antara PT. PN III Dengan SPBUN PT. PN III, yang menentukan kriteria bagi pekerja wanita untuk dapat diperlakukan sebagai kepala keluarga dan akan gugur statusnya apabila menikah kembali, yang jika dikaji berdasarkan ketentuan Pasal 1338 KUH 
Perdata ketentuan pasal tersebut masih bertentangan dengan berbagai ketentuan pasal dari undang-undang yang berlaku, sehingga perjanjian kerja bersama tersebut belum dapat diberlakukan sebagai undang-undang bagi para pihak yang terikat.

Penyebab lebih diutamakannya perekrutan pekerja pria dari pada pekerja wanita pada PT. PN III adalah karena pekerja pria bekerja lebih efektif dari pada pekerja wanita. Berdasarkan hukum, hal ini tidak dapat dijadikan sebagai alasan pembenar bagi PT. PN III, karena jelas merupakan bentuk diskriminasi yang menimbulkan ketidakadilan bagi pekerja wanita, dan juga jelas bertentangan dengan ketentuan Pasal 27 ayat (1), ayat (2), Pasal 28 D ayat (1), ayat (2) UUD 1945, dan Pasal 4 UU Nomor 39 Tahun 1999.

\section{DAFTAR PUSTAKA}

Anoraga, P, (1995). BUMN, Swasta, dan Koperasi (Tiga Pelaku Ekonomi), Dunia Pustaka Jaya, Jakarta.

Asshiddiqie, J. (2012). Hukum Tata Negara dan Pilar-pilar Demokrasi, Sinar Grafika, Jakarta.

Atmadja, I.D.G. (2010) Hukum Konstitusi (Problematik Konstitusi Indonesia Sesudah Perubahan UUD NRI 1945), Setara Press, Malang.

Beckmann, F.Y.B. (1983). Why Does not Behave (Critical and Constructive Reflection on The Social Scientific Perception of The Social Significance of Law), Vancouver, Xith International Congress of IUEAS, Canada.

Bertens, K. (2000). Pengantar Etika Bisnis, Kanisius, Yogyakarta,

Daniel, W. dan Mohamed, G.H. (2008), Teaching Material on Jurisprudence, Ethiopian Justice and Legal Research Institute.

Davies, H, dan Holdcroft, D. (1991). Jurisprudence (Text and Commentary), Butterworths, London.

Friedman, L.M. (1977). Law and Society (An Introduction), Prentice-Hall Inc., Englewood Cliffs, New Jersey.

Hadjon, P.M. (1987). Perlindungan Hukum Bagi Rakyat Indonesia, Bina Ilmu, Surabaya.

Harahap, M.Y. (1997). Beberapa Tinjauan Tentang Permasalahan Hukum, Citra Aditya Bakti, Bandung,

Hartono, S.R. et.al. (2006). Permasalahan Seputar Hukum Bisnis (Persembahan Kepada Sang Maha Guru), Yogyakarta.
Khairandy, R, (2019). Perseroan Terbatas (Doktrin, Peraturan Perundang-undangan, dan Yurisprudensi), Kreasi Total Media, Yogyakarta,

KUH Perdata

M.C. Burkens, (1990). Beginselen van de Democratische Rechts Staat, Tjeenk Willink, Zwole.

Martosoewigyo, R.S.S. (1992). Bunga Rampai Hukum Tata Negara Indonesia, Alumni, Bandung.

Mertokusumo, S. (1991). Mengenal Hukum (Suatu Pengantar), Liberty, Yogyakarta.

Naldo, R.A.C. dan Sirait, N.N.S. (2017)., Implementation of Corporate Absolute Responsibility for Land Fires Causing Air Pollution, International Conference on Public Policy, Social Computing and Development, Advances in Social Science, Education and Humanities Research, Volume 141, Hal. 57.

Nasution, D, dan Sirait, N.N. (2017). Urgency of Local-Owned Enterprises (BUMD) Law as Good Corporate Governance Basis in Indonesia, International Conference on Public Policy, Social Computing and Development, Advances in Social Science, Education and Humanities Research, Volume 141. Hal. 113.

Nonet, P. and Selznick, P, (1978). Law and Society in Transition, Toward Responsive Law, Harper \& Row, Newyork,

Rahardjo, S. (2006). Ilmu Hukum, Citra Aditya Bakti, Bandung,

Rasjidi, L. dan Putra, I.B.W. (1993). Hukum Sebagai Suatu Sistem, Remaja Rosdakarya, Bandung.

Rawls, J. (1971). A Theory of Justice, The Belknap Press of Harvard University Press, Cambrige.

Sitorus, 0 dan Sierrad, H.M.Z. (2006). Hukum Agraria di Indonesia (Konsep Dasar, dan Implementasi), Mitra Kebijakan Tanah Indonesia, Yogyakarta,

Soekanto, S, (1993). Faktor-faktor yang Mempengaruhi Penegakan Hukum, Raja Grafindo Persada, Jakarta.

Soekanto, S. (1986). Pengantar Penelitian Hukum, Universitas Indonesia Press, Jakarta,

Soekanto, S. dan Mamuji, S, (2004). Penelitian Hukum Normatif, Raja Grafindo Persada, Jakarta.

Soemitro, R. (1976). Peradilan Administrasi Dalam Hukum Pajak di Indonesia, Eresco, Bandung.

Soemitro, R.H. (1988). Metodologi Penelitian Hukum dan Jurimetri, Ghalia Indonesia, Jakarta.

Sunggono, B. (2002). Penelitian Hukum (Suatu Pengantar), Raja Grafindo Persada, Jakarta,

Syahrin, A. (2009). Beberapa Masalah Hukum, Sofmedia, Medan. 
Undang-undang Nomor 13 Tahun 2003 tentang Ketenagakerjaan (UU Nomor 13 Tahun 2003),

Undang-undang Nomor 17 Tahun 2003 (UU Nomor 17 Tahun 2003), yang menentukan bahwa: "Perusahaan negara adalah badan usaha yang seluruh atau sebagian modalnya dimiliki oleh Pemerintah Pusat".

Undang-undang Nomor 39 Tahun 1999 tentang Hak Asasi Manusia (UU Nomor 39 Tahun 1999),
Undang-undang Nomor 40 Tahun 2007 tentang Perseroan Terbatas (UU Nomor 40 Tahun 2007),

UU Nomor 13 Tahun 2003

UU Nomor 13 Tahun 2003,

UU Nomor 13 Tahun 2003,

UU Nomor 39 Tahun 1999

UU Nomor 39 Tahun 1999

UU Nomor 39 Tahun 1999,

UUD 1945, 